\title{
ANALISIS FAKTOR KERUGIAN WASTE MATERIAL BESI BETON GEDUNG BERTINGKAT
}

\author{
Hendrik Sulistio', Mega Waty ${ }^{2}$ \\ ${ }^{1}$ Program Studi Doktor Teknik Sipil Universitas Tarumanagara \\ Email:hendriks@ft.untar.ac.id \\ ${ }^{2}$ Program Studi Sarjana Teknik Sipil Universitas Tarumanagara \\ Email :mega@ft.untar.ac.id
}

\begin{abstract}
ABSTRAK
Material sebagai salah satu komponen yang mempunyai kontribusi sebesar 40-60\% dari biaya proyek di dalam penelitian Intan et al, 2005. Besi beton saat ini mau diteliti karena merupakan salah satu dari lima material mempengaruhi $80 \%$ biaya material. Tujuan penelitian ini meneliti berapa besar kerugian waste material besi beton dan peringkat faktor faktor yang mempengaruhinya pada proyek bangunan gedung bertingkat . Metode penelitian dengan melakukan kuesioner terhadap kontraktor. Proses pengumpulan data yang dilakukan adalah dengan menyebar kuesioner di proyek bangunan gedung bertingkat yang berada di Jakarta. Pengukuran nilai kuesioner sebanyak 64 responden digunakan teknik pengukuran Likert. Urutan pengolahan data, pertama dilakukan dengan uji validitas dan uji reliabilitas. Setelah itu faktor-faktor tersebut ditentukan peringkat dengan metode Relative Importance Index. Hasilnya adalah kerugian waste material Besi Beton sebesar 7,5\% dan peringkat yang mempengaruhi kerugian besi beton adalah:tidak merencanakan bestat penulangan, pendetailan gambar yang rumit, kesalahan pemotongan karena kurang memahami gambar kerja/kecerobohan,informasi gambar kurang/tidak jelas, penggunaan material yang salah sehingga perlu diganti, sisa pemotongan karena proses pemakaian dan adanya perubahan desain.
\end{abstract}

Kata Kunci: bangunan gedung bertingkat; besi beton; waste material

\begin{abstract}
Material as one of the components that has a contribution of 40-60\% of the project cost in the research of Intan et al., 2005. Concrete is currently being studied because it is one of the five materials that affects $80 \%$ of material costs. The purpose of this research is to examine how much the loss of iron concrete material waste and the ranking of the factors that influence it in multi-storey building projects. The research method is by conducting a questionnaire to contractors. The data collection process is carried out by distributing questionnaires in multistorey building projects in Jakarta. Measuring the value of the questionnaire as many as 64 respondents used the Likert measurement technique. The sequence of data processing, first done by testing the validity and reliability testing. After that, these factors are ranked using the Relative Importance Index method. The result is a loss of Concrete Iron material waste of $7.5 \%$ and ratings that affect the loss of concrete are: not planning reinforcement bestat, complicated image detailing, cutting errors due to lack of understanding of work drawings / carelessness, lack of / unclear image information, use of wrong so that it needs to be replaced, the remaining cuts due to the process of use and a design change.
\end{abstract}

Keywords: multi-storey building; reinforcing steel; waste material

\section{PENDAHULUAN}

Material waste merupakan istilah dari besarnya persentase waste material yang terjadi dan merupakan salah satu permasalahan yang serius pada pelaksanaan proyek konstruksi jalan. Material sebagai salah satu komponen yang mempunyai kontribusi sebesar 40-60\% dari biaya proyek (Ritz, 1994)di dalam penelitian Intan et al, (2005) yang menyatakan bahwa material turut memegang peranan penting dalam menunjang keberhasilan suatu proyek. Penelitian dari Intan et al, 2005 penelitian terhadap kuantitas material waste yang paling banyak pada proyek 
gedung yakni batu bata dan pasir sebesar $12,51 \%$ dan pasir 11,39\%. Dari kedelapan jenis material yang secara signifikan mempengaruhi $80 \%$ biaya material waste adalah besi beton, keramik, semen, beton ready mix, dan batu bata. Total biaya material waste yang terjadi 3,68\% . Besi beton saat ini mau diteliti karena merupakan salah satu dari lima material mempengaruhi $80 \%$ biaya material. Waste material telah diakui sebagai masalah utama dalam industri konstruksi yang memiliki implikasi penting bagi keduanya industri efisiensi dan untuk dampak lingkungan dari proyek konstruksi (Formoso et al., 2002) Formoso et al., 2002 menghasilkan penelitian dari dua studi penelitian yang dilakukan di Brasil yang menyelidiki terjadinya waste material di 74 lokasi bangunan yang terletak di berbagai wilayah di negara itu. Hasil penelitian menunjukkan bahwa material waste Industri bangunan Brasil cukup tinggi dan variabilitas besar dalam kejadian waste ditemukan di berbagai proyek. Kebanyakan dari ini menyatakan waste dapat dihindari dengan menerapkan tindakan pencegahan yang tidak mahal, kebanyakan terkait dengan perbaikan manajerial.

Waste material telah diakui sebagai masalah utama dalam industri konstruksi yang dimilikinya dan implikasi penting baik untuk industri efisiensi dan untuk dampak lingkungan proyek konstruksi. (Formoso et al., 2002). Waste material merupakan istilah dari besarnya persentase material waste dan merupakan salah satu masalah serius dalam pelaksanaan proyek pembangunan jalan (Waty et al., 2018) Hasil penelitian adalah untuk menghitung persentase rata-rata material waste pada proyek pembangunan jalan dan memperoleh material waste yang mempengaruhi profit serta membuat model regresi dari\% material waste menjadi\% profit kontraktor (Waty et al., 2018). Penelitian terdahulu yakni pada waste material beton ready mix yang mempunyai kerugian sebesar 9,02\% pada proyek Gedung bertingkat di Jakarta (Sulistio dan Waty,2020) .Penelitian Haposan, 2009 menyatakan bahwa waste besi beton ulir D16 memiliki waste cost terbesar, yaitu Rp.53,618,041.938 pada proyek ruko San Diego di Pakuwon City Surabaya. Waste cost perlu diketahui terlebih dahulu material trading yang akan diteliti berdasarkan biaya material yang terbesar melalui diagram pareto (Haposan, 2009) Tujuan penelitian ini meneliti berapa besar kerugian waste material besi beton dan peringkat faktor faktor yang mempengaruhinya pada proyek bangunan gedung bertingkat.

\section{Rumusan Masalah}

Perumusan masalah adalah:

a. Berapa persentase kerugian waste material besi beton bangunan gedung bertingkat?

b. Bagaimana peringkat faktor yang mempengaruhi kerugian waste material besi beton?

\section{METODE PENELITIAN}

Metode penelitian dengan melakukan kuesioner terhadap kontraktor. Proses pengumpulan data yang dilakukan adalah dengan menyebar kuesioner di proyek bangunan gedung bertingkat yang berada di Jakarta Untuk pengukuran nilai kuesioner digunakan teknik pengukuran Likert Keterangan untuk skala pengukuran faktor yang mempengaruhi kerugian besi beton pada proyek Gedung bertingkat adalah:dari sangat tidak berpengaruh hingga sangat berpengaruh sekali dari skala 1-6 (Likert,1932). Responden adalah staf kontraktor antara lain manajer lapangan, pengawas lapangan, pelaksana lapangan dan mandor. Urutan pengolahan data diawali dengan pertama dilakukan uji validitas dan uji reliabilitas. Setelah itu faktor-faktor tersebut ditentukan peringkat dengan metode Relative Importance Index. Dari hasil 64 responden yang mengembalikan kuisioner maka dilakukan uji validitas dan reliabilitas. 


\section{Uji Validitas}

Baik atau tidaknya suatu instrumen penelitian ditentukan oleh validitas dan reliabilitasnya. Validitas instrumen mempermasalahkan sejauh mana pengukuran tepat dalam mengukur apa yang hendak diukur. Pengukuran validitas dengan membandingkan nilai $\mathrm{r}$ perhitungan (Product Moment) dengan nilai $\mathrm{r}$ pada tabel. Jika nilai $\mathrm{r}$ hitung $\geq \mathrm{r}$ tabel, maka data tersebut sudah valid. Rumus yang digunakan untuk mencari koefisien Product Moment (Pearson, 1896) yaitu:

$$
r_{x y}=\frac{n \sum x y-\left(\sum x\right)\left(\sum y\right)}{\sqrt{\left(n \sum x^{2}-\left(\sum x\right)^{2}\right)\left(n \sum y^{2}-\left(\sum y\right)^{2}\right)}} \ldots \ldots \ldots . . .(1)
$$

Keterangan:

$\mathrm{x} \quad$ : skor yang diperoleh subjek dari seluruh item

y : skor total yang diperoleh dari seluruh item

$\Sigma \mathrm{x} \quad$ : jumlah skor dalam distribusi $\mathrm{x}$

$\Sigma y \quad$ : jumlah skor dalam distribusi y

$\Sigma \mathrm{x}^{2} \quad$ : jumlah kuadrat dalam skor distribusi $\mathrm{x}$

$\Sigma y^{2} \quad$ : jumlah kuadrat dalam skor distribusi y

$\mathrm{n} \quad$ : banyaknya responden

\section{Uji Reliabilitas}

Reliabilitas adalah alat untuk mengukur suatu kuesioner yang merupakan indikator dari peubah atau konstruk. Suatu kuesioner dikatakan reliabel atau handal jika jawaban seseorang terhadap pernyataan adalah konsisten atau stabil dari waktu ke waktu. Pengujian reliabilitas instrumen dengan menggunakan rumus Alpha Cronbach karena instrumen penelitian ini berbentuk angket dan skala bertingkat.

Rumus untuk mencari nilai cronbach's alpha (Cronbach, 1951)sebagai berikut:

$$
r_{11}=\left(\frac{n}{n-1}\right)\left(1-\frac{\sum \sigma_{t}^{2}}{\sigma_{t}^{2}}\right) \ldots \ldots \ldots . .(2)
$$

Keterangan:

$$
\begin{array}{ll}
r_{11} & \text { : koefisien reliabilitas (cronbach's alpha value } \\
\mathrm{n} & : \text { banyak butiran pernyataan } \\
\Sigma \sigma_{i}{ }^{2} & \text { : jumlah varians skor soal ke-i } \\
\sigma_{t}{ }^{2} & \text { : jumlah varians skor total }
\end{array}
$$

\section{Relative Importance Index ( RII)}

Setelah didapat data dari kuesioner berupa skala likert dengan skala 1 6, dimana Skala 1 menunjukan faktor sangat tidak berpengaruh terhadap besi beton dan skala 6 menunjukan faktor sangat berpengaruh terhadap besi beton. Setelah beberapa variabel/faktor dieliminasi dengan uji validitas dan reliabilitas, langkah selanjutnya dilakukan Relative Importance Index untuk mengetahui peringkat faktor yang mempengaruhi besi beton.

Relative Importance Index dapat dihitung menggunakan rumus dibawah ini : (Waty dan Sulistio,2020).

$$
R I I(\%)=\frac{6 n 6+5 n 5+4 n 4+3 n 3+2 n 2+1 n 1}{W *(n 6+n 5+n 4+n 3+n 2+n 1)} \times 100 \% .
$$


Keterangan:

n6 : Jumlah responden yang memilih skala 6

n5 : Jumlah responden yang memilih skala 5

n4 : Jumlah responden yang memilih skala 4

n3 : Jumlah responden yang memilih skala 3

n2 : Jumlah responden yang memilih skala 2

n1 : Jumlah responden yang memilih skala 1

W : Skala terbesar dalam skala likert

\section{HASIL DAN PEMBAHASAN}

\section{Kuantitas Waste Material}

Data 64 responden menghasilkan rata rata sebesar 7,5\% yang merupakan kerugian besi beton Faktor penyebab waste material besi beton merujuk pada beberapa referensi yang dapat di lihat pada Tabel 1 Faktor Penyebab Waste Material Besi Beton.

Tabel 1. Faktor Penyebab Waste Material Besi Beton

\begin{tabular}{cll}
\hline Sumber & Penyebab & Referensi \\
\hline Desain & Adanya perubahan desain & Bossink,1996 \\
& Informasi gambar kurang/tidak jelas & Bossink,1996 \\
& $\begin{array}{c}\text { Pendetailan gambar yang rumit } \\
\text { Kurang berkoordinasi terhadap dimensi } \\
\text { produk yang digunakan }\end{array}$ & Bossink,1996 \\
Bossink,1996 \\
\hline Pengadaan & Pesanan material tidak sesuai spesifikasi & Bossink,1996 \\
& Pemesanan melebihi kebutuhan & Bossink,1996 \\
& Pesanan tidak dapat dilakukan dalam & Bossink,1996 \\
& jumlah kecil & Bossink,1996 \\
& Supplier kirim material tidak sesuai & \\
& spesifikasi & Bossink,1996 \\
\hline Pelaksanaan & Kesalahan pemotongan karena salah & Bossink,1996 \\
& memahami gambar kerja/kecerobohan & Bossink,1996 \\
& Penggunaan material yang salah sehingga & Bossink,1996 \\
& perlu diganti & \\
& Informasi tipe/ukuran besi beton terlambat & \\
& disampaikan kepada kontraktor & Bossink,1996 \\
& Tidak merencanakan bestat penulangan & Intan et \\
& & al,2005 \\
\hline Residual & Sisa material karena proses pemakaian & Bossink,1996 \\
\hline Lain lain & Hilang karena dicuri & Bossink,1996 \\
\hline
\end{tabular}




\section{Uji Validitas}

Uji validitas merupakan uji untuk mengukur valid atau tidaknya suatu kuesioner. Uji validitas ini akan dilakukan dengan menggunakan program bantu dimana dengan metode analisis bivariate. Dimana inti dari analisis ini ialah untuk mengeluarkan nilai product moment ( $\mathrm{r}$ hitung).

Nilai $r$ hitung ini nantinya akan dibandingkan dengan nilai $r$ tabel dengan tingkat signifikansi 5\% dimana nilai $r$ tabel untuk responden sebanyak 64 orang yaitu 0,244. Apabila nilai $r$ hitung lebih besar dari nilai $r$ tabel, maka variabel penelitian tersebut valid.

Uji validitas dilakukan pada desain, pengadaan, pelaksanaan dan residual lain lain, salah satunya yakni uji validitas Desain. Uji validitas menghasilkan output pada desain dari desain 1 hingga desain 4 menghasilkan nilai validitas yang tinggi yang melebihi tabel $\mathrm{R}$ momen product $(0,244)$ sehingga semua faktor yang berpengaruh di dalamnya layak dipergunakan baik dari perhitungan validitas berdasarkan Tabel 2. Output Uji Validitas (item total corrected) Desain . Demikian pula dengan ouput uji validitas Tabel 3, output uji validitas Pengadaan Tabel 4, Output uji validitas Pelaksanaan Tabel 5. Output uji validitas Residual dan lain lain.

Tabel 2. Uji Validitas Desain

\begin{tabular}{lcrrr}
\hline & $\begin{array}{c}\text { Scale Mean } \\
\text { if Item } \\
\text { Deleted }\end{array}$ & $\begin{array}{c}\text { Scale } \\
\text { Variance if } \\
\text { Item Deleted }\end{array}$ & $\begin{array}{c}\text { Corrected } \\
\text { Item-Total } \\
\text { Correlation }\end{array}$ & $\begin{array}{c}\text { Cronbach's } \\
\text { Alpha if } \\
\text { Item Deleted }\end{array}$ \\
\hline Desain 1 & 12.2031 & 13.339 & .637 & .782 \\
\hline Desain 2 & 12.1563 & 13.499 & .686 & .760 \\
\hline Desain 3 & 12.0000 & 12.952 & .759 & .727 \\
\hline Desain 4 & 12.3438 & 14.197 & .522 & .836 \\
\hline
\end{tabular}

Uji validitas menghasilkan output pada desain dari desain 1 hingga desain 4 menghasilkan nilai validitas yang tinggi yang melebihi tabel $\mathrm{R}$ momen product $(0,244)$ sehingga semua faktor yang berpengaruh di dalamnya layak dipergunakan baik dari perhitungan validitas berdasarkan tabel 2. Output Uji Validitas (item total corrected).

Tabel 3. Output Uji Validitas Pengadaan Item Total Statistics

\begin{tabular}{lrrrr}
\hline & $\begin{array}{c}\text { Scale Mean } \\
\text { if Item } \\
\text { Deleted }\end{array}$ & $\begin{array}{c}\text { Scale } \\
\text { Variance if } \\
\text { Item Deleted }\end{array}$ & $\begin{array}{c}\text { Corrected } \\
\text { Item-Total } \\
\text { Correlation }\end{array}$ & $\begin{array}{c}\text { Cronbach's } \\
\text { Alpha if } \\
\text { Item Deleted }\end{array}$ \\
\hline Pengadaan 1 & 11.1719 & 15.541 & .637 & .721 \\
\hline Pengadaan 2 & 11.1719 & 15.764 & .610 & .735 \\
\hline Pengadaan 3 & 11.4219 & 17.010 & .547 & .765 \\
\hline Pengadaan 4 & 11.5156 & 15.682 & .609 & .736 \\
\hline
\end{tabular}


Tabel 4. Output Uji Validitas Pelaksanaan Item-Total Statistics

\begin{tabular}{lcrrr}
\hline & $\begin{array}{c}\text { Scale Mean } \\
\text { if Item } \\
\text { Deleted }\end{array}$ & $\begin{array}{c}\text { Scale } \\
\text { Variance if } \\
\text { Item Deleted }\end{array}$ & $\begin{array}{c}\text { Corrected } \\
\text { Item-Total } \\
\text { Correlation }\end{array}$ & $\begin{array}{c}\text { Cronbach's } \\
\text { Alpha if } \\
\text { Item Deleted }\end{array}$ \\
\hline Pelaksanaan 1 & 12.5625 & 14.091 & .690 & .821 \\
\hline Pelaksanaan 2 & 12.6719 & 12.351 & .774 & .785 \\
\hline Pelaksanaan 3 & 12.7344 & 13.055 & .735 & .802 \\
\hline Pelaksanaan 4 & 12.2344 & 15.611 & .611 & .852 \\
\hline
\end{tabular}

Tabel 5. Uji Validitas Residual dan lain lain

\begin{tabular}{lrrrr}
\hline & $\begin{array}{c}\text { Scale Mean } \\
\text { if Item } \\
\text { Deleted }\end{array}$ & $\begin{array}{c}\text { Scale } \\
\text { Variance if } \\
\text { Item Deleted }\end{array}$ & $\begin{array}{c}\text { Corrected } \\
\text { Item-Total } \\
\text { Correlation }\end{array}$ & $\begin{array}{c}\text { Cronbach's } \\
\text { Alpha if } \\
\text { Item Deleted }\end{array}$ \\
\hline Residual & 3.9688 & 2.951 & .557 & \\
\hline lain lain & 4.0625 & 2.282 & .557 & \\
\hline
\end{tabular}

\section{Uji Reliabilitas}

Uji ini digunakan untuk mengetahui apakah alat ukur pada kuesioner ini konsistensi atau tidak. Uji ini menggunakan metode Alpha Conbrach's. Apa bila nilai Alpha Conbrach's kurang dari 0,6 maka alat ukur dikatakan tidak reliabel. Sedangkan lebih dari 0,6 (Gozali, 2001) maka alat ukur dikatakan reliabel.

Hasil output reliabilitas seluruh faktor menyatakan 0,920>0,6 maka dapat dikatakan reliabel sehingga seluruh faktor dari desain hingga lain lain dapat dipergunakan yang dapat dilihat pada Tabel 6. Demikian pula untuk per bidang faktor dapat dilihat pada Tabel 7 dengan hasil output melebihi dari R Tabel $(0,6)$.

Tabel 6. Uji Reliabilitas Seluruh Faktor

\begin{tabular}{cr}
\multicolumn{2}{c}{ Reliability Statistics } \\
\hline $\begin{array}{c}\text { Cronbach's } \\
\text { Alpha }\end{array}$ & $\begin{array}{c}\text { N of } \\
\text { Items }\end{array}$ \\
\hline .920 & 14 \\
\hline
\end{tabular}

Tabel 7. Hasil Uji Reliabilitas Per Jenis Faktor

\begin{tabular}{llll}
\hline No & Jenis & R $\boldsymbol{\alpha}$ & $\begin{array}{l}\mathbf{R} \\
\text { tabel }\end{array}$ \\
\hline 1 & Desain & 0.823 & 0.6 \\
\hline 2 & Pengadaan & 0.791 & 0.6 \\
\hline 3 & Pelaksanaan & 0.856 & 0.6 \\
\hline 4 & Residual & 0.712 & 0.6 \\
\hline
\end{tabular}




\section{Relative Importance Index ( RII)}

Cichetti, 1994 menyatakan bahwa suatu survey dikatakan sangat baik bila mempunyai nilai antara 0,75 hingga 1 , dan disebut baik jika berkisar dari nilai 0,6-0,74. Hasil dari penelitian ini menunjukkan range antar 0,6-0,74, sehingga dapat dikatakan hasil perhitungan ini menunjukkan hasil yang baik. Tabel dibawah ini menunjukkan hasil RII yang baik mengingat berkisar antara $0,6-0,75$.

Tabel 8 Nilai Perhitungan RII untuk setiap faktor

\begin{tabular}{lc}
\hline $\begin{array}{l}\text { Faktor yang mempengaruhi kerugian besi beton } \\
\text { Desain }\end{array}$ & RII \\
\hline Adanya perubahan desain & $\mathbf{0 . 6 7 2}$ \\
\hline Informasi gambar kurang/tidak jelas & $\mathbf{0 , 6 8 0}$ \\
\hline - Pendetailan gambar yang rumit & $\mathbf{0 . 7 0 6}$ \\
\hline $\begin{array}{l}\text { Kurang berkoordinasi terhadap dimensi produk yang } \\
\text { digunakan }\end{array}$ & $\mathbf{0 . 6 4 8}$ \\
\hline Pengadaan Material & $\mathbf{0 . 6 5 4}$ \\
\hline Pesanan material tidak sesuai spesifikasi & $\mathbf{0 , 6 5 4}$ \\
\hline Pemesanan melebihi kebutuhan & $\mathbf{0 , 6 1 2}$ \\
\hline Pesanan tidak dapat dilakukan dalam jumlah kecil & $\mathbf{0 , 5 9 6}$ \\
\hline Supplier kirim material tidak sesuai spesifikasi & $\mathbf{0 , 6 9 5}$ \\
\hline Pelaksanaan Material & $\mathbf{0 , 6 7 7}$ \\
\hline $\begin{array}{l}\text { Kesalahan pemotongan karena salah memahami gambar } \\
\text { kerja/kecerobohan }\end{array}$ & $\mathbf{0 , 6 6 7}$ \\
\hline Penggunaan material yang salah sehingga perlu diganti \\
\hline $\begin{array}{l}\text { Informasi tipe/ukuran besi beton terlambat disampaikan } \\
\text { kepada kontraktor }\end{array}$ \\
\hline Tidak merencanakan bestat penulangan \\
\hline Residual & $\mathbf{0 , 7 5 0}$ \\
\hline Sisa pemotongan karena proses pemakaian \\
\hline Lain Lain \\
\hline Hilang karena dicuri \\
\hline
\end{tabular}

Tabel 9 Nilai Perhitungan RII rerata untuk Penyebab kerugian Besi Beton

\begin{tabular}{cc}
\hline $\begin{array}{c}\text { Faktor yang mempengaruhi Kerugian } \\
\text { Besi Beton }\end{array}$ & Nilai rata-rata RII \\
\hline Desain & 0,676 \\
\hline Pengadaan Material & 0,629 \\
\hline Pelaksanaan & 0,697 \\
\hline Residual & 0.677 \\
\hline Lain lain & 0,651 \\
\hline
\end{tabular}

\section{KESIMPULAN DAN SARAN}

Setelah dilakukan pengolahan data hasil penelitian, dapat ditarik kesimpulan beberapa hal yaitu:

1. Kerugian waste material Besi Beton sebesar 7,5\%

2. Peringkat faktor yang mempengaruhi kerugian waste material besi beton adalah :

- Tidak merencanakan bestat penulangan

- Pendetailan gambar yang rumit

- Kesalahan pemotongan karena kurang memahami gambar kerja/kecerobohan 
- Informasi gambar kurang/tidak jelas

- Penggunaan material yang salah sehingga perlu diganti

- Sisa pemotongan karena proses pemakaian

Saran penelitian :

1. Lebih memperhatikan perencanaan bestat penulangan besi beton

2. Lebih memperhatikan kesalahan pemotongan besi beton

3. Lebih memperhatikan pendetailan gambar

\section{Ucapan Terima Kasih}

Ucapan terima kasih ditujukan kepada Lembaga Penelitian dan Pengabdian Masyarakat Universitas Tarumanagara yang sudah mendanai penelitian ini.

\section{REFERENSI}

Bossink, B. A. G., \& Brouwers, H. J. H. (1996). Construction waste: quantification and source evaluation. Journal of construction engineering and management, 122(1), 55-60.

Cichetti, D. V. (1994). Guidelines, criteria, and rules of thumb for evaluating normed and standardized assessment instruments in psychology. Psychological assessment, 6(4), 284.

Cronbach, L. J. (1951). Coefficient alpha and the internal structure of tests. Psychometrika, 16(3), 297-334

Formoso, C. T., Soibelman, L., De Cesare, C., \& Isatto, E. L. (2002). Material waste in building industry: main causes and prevention. Journal of construction engineering and management, 128(4), 316-325.

Gozali, I. (2001). Aplikasi Analisis Multivariate. Dengan_Program SPSS. Edisi Pertama. Semarang: Badan Penerbit Universitas Diponegoro.

Haposan, J. (2009). Identifikasi Material Sisa pada Proyek Ruko San Diego PakuwonCity Surabaya. Skripsi, Institut Teknologi Sepuluh November Surabaya.

Intan, S., Alifen, R. S., \& Arijanto, L. S. (2005). ANALISA DAN EVALUASI SISA MATERIAL KONSTRUKSI SUMBER PENYEBAB KUANTITAS DAN BIAYA. Civil Engineering Dimension, 7(1), pp-36.

Likert RA. (1932). Technique for the measurement of attitudes. Archives of Psychology, 140 pp: $1-55$

Pearson, K. (1896), "Mathematical Contributions to the Theory of Evolution. III. Regression, Heredity and Panmixia," Philosophical Transactions of the Royal Society of London, 187, 253-318

Ritz, G. J. (1994) "Total construction project management" McGraw-Hill Book Company. practice. Reprinted from Building Research and Practice, July/August 1976. Journal of Social Issues, 32.

Waty, M., \& Sulistio, H. (2020). PERHITUNGAN CHANGE ORDER PROYEK JALAN DI BANTEN. Jurnal Muara Sains, Teknologi, Kedokteran dan Ilmu Kesehatan, 4(2), 211220.

Waty, M., Alisjahbana, S. W., Gondokusumo, O., Sulistio, H., Hasyim, C., Setiawan, M. I., ... \& Ahmar, A. S. (2018). Modelling of waste material costs on road construction projects. 